\title{
ANALISIS KELAYAKAN USAHA TERNAK KELINCI (Kelompok Ternak Kelinci "Sumber Lestari" Desa Sumber Kecamatan Sanankulon Kabupaten Blitar)
}

\author{
Rosyida Fajarini,S.Pt, MP \\ Dosen Prodi Ilmu Ternak Fakultas Peternakan \\ Universitas Islam Balitar \\ Jl. Majapahit No 04 , Blitar Jawa Timur, Indonesia
}

\begin{abstract}
The study was started on May 1, 2012 through June 15, 2012 in the rabbit animal group "SUMBER LESTARI" Sumber Village Sanankulon subdistrict Blitar District. The purpose of this Thesis are to (1) determine the expenditure and revenue of the rabbit animal group "SUMBER LESTARI", (2) determine the feasibility of the rabbit animal group "SUMBER LESTARI".

The material obtained from this study were in the rabbit animal group "SUMBER LESTARI" Sumber Village Sanankulon subdistrict Blitar District by the number of respondents as many as 17 people. The research method used in this thesis research is descriptive method that is trying to tell the current problem solving based on the data, so it presents research data, analyze and interpret.

The results of this study were (1) The amount of expenditures and receipts of the rabbit animal group "SUMBER LESTARI" is an average of Rp. 1.971.529/year for expenses while receiving an average of Rp. 2.126.659/year, (2) The the rabbit animal group "SUMBER LESTARI" worth the try. It can be seen from the R/C by an average of 1.074 and the value of B /C average of 0.074 .
\end{abstract}

Keywords : rabbit, feasibility, recipts.

\section{Pendahuluan}

Dewasa ini bidang peternakan memegang peranan penting dalam pembangunan nasional Indonesia. Bidang peternakan memiliki kontribusi dalam memenuhi kebutuhan hidup manusia yaitu berupa komoditi utama seperti daging, telur, susu, maupun produk sampingan berupa kotoran. Saat ini salah satu jenis ternak yang mempunyai potensi besar untuk dikembangkan adalah ternak kelinci. Sehingga dapat mengurangi ketergantungan terhadap bahan pangan hewani impor.

Ternak kelinci bila dipelihara secara intensif dapat beranak sampai 4-6 kali setahun dengan kemampuan menghasilkan anak 4-10 ekor per kelahiran, sehingga usaha ternak ini cukup menjanjikan keuntungan. Ternak ini mudah dan sederhana dalam pemeliharaannya serta tidak memerlukan lahan yang luas. Selain itu daging kelinci mempunyai keunggulan dibandingkan daging asal ternak lainnya yaitu rendahnya kadar kolesterol, tinggi protein serta seratnya pendek dan halus sehingga cocok untuk dikonsumsi oleh anak-anak hingga orang dewasa. Kelinci juga dipelihara secara komersil untuk diambil daging, Fur (kulit - bulu) serta untuk fancy dan hewan percobaan di laboratorium. Hal ini memberikan nilai tambah bagi komoditas ternak kelinci untuk dikembangkan.

Saat ini upaya pengembangan ternak kelinci tampaknya belum maksimal, mengingat jumlah peternakan kelinci maupun populasi tidak menunjukkan perkembangan berarti. Hal ini 
disebabkan kurang diarahkannya penjajagan kepastian pasar terlebih dahulu, kurang populernya daging kelinci di masyarakat, dan adanya anggapan dari masyarakat bahwa mereka akan mengembangkan usaha ternak kelinci jika lebih menguntungkan dibandingkan usaha lain. Kelinci selalu memiliki pesona tersendiri bagi masyarakat. Ia bukan sekedar hewan piaraan yang menghasilkan daging atau uang hasil penjualan, melainkan sebagai kesenangan "berselera tinggi" dengan ciri khas yang eksklusif. Hanya saja karena pemeliharaan di masyarakat kita cenderung tradisional dan tidak mengikuti kaidah pemeliharaan kelinci secara tepat dan baik, akhirnya banyak yang gulung tikar.

Selama ini peternakan kelinci di Indonesia masih diusahakan sebagai peternakan keluarga yang bersifat sambilan. Kegiatan budidaya dan manajemennya masih sangat sederhana, sebagai alternatif usaha peternakan kelinci sebenarnya dapat dikembangkan dalam bentuk peternakan. Sasarannya produksi dapat ditingkatkan sesuai dengan target, mutu dan penerimaan pasar yang berkembang (Sarwono, 2005).

Hal yang dapat menjadi pertimbangan seseorang jika ingin mendirikan suatu usaha adalah kelayakan usaha tersebut yang sebenarnya. Salah satu kriteria yang dapat menjadi acuan apakah suatu usaha bisa dikatakan layak atau tidak adalah keuntungan, karena sebagian besar usaha peternakan kelinci merupakan usaha peternakan rakyat maka tidak semua biaya-biaya produksi dihitung dengan teliti sehingga tidak mengetahui keuntungan bersih dan kelayakan usaha tersebut yang sesungguhnya. Biaya-biaya produksi tersebut misalnya tenaga kerja, penyusutan peralatan dan penyusutan kandang.

Analisis kelayakan usaha merupakan cara untuk mengetahui apakah usaha tersebut sebenarnya layak atau tidak untuk dilakukan. Hal tersebut sangat bermanfaat bagi peternak kelinci dalam menjaga kelangsungan dan memajukan usahanya. Selain itu, dapat mendorong masyarakat untuk mengembangkan usaha peternakan kelinci. Diperlukan dukungan dari pihakpihak terkait untuk dapat membantu pengembangan usaha peternakan kelinci di Indonesia. Bila usaha peternakan kelinci semakin berkembang maka akan dapat mengurangi ketergantungan terhadap bahan pangan hewani impor dan meningkatkan kesejahteraan para pelaku usaha peternakan kelinci. Tujuan yang ingin dicapai penelitian di kelompok ternak kelinci "SUMBER LESTARI" Desa Sumber yaitu Untuk mengetahui pengeluaran,penerimaan usaha dan kelayakan usaha kelompok ternak kelinci "SUMBER LESTARI".

\section{Materi Dan Metode Penelitian}

Kegiatan penelitian dilaksanakan di kelompok ternak kelinci "SUMBER LESTARI" Desa Sumber Kecamatan Sanankulon Kabupaten Blitar. Lokasi tersebut dipilih karena memiliki ternak kelinci dengan populasi yang cukup banyak. Adapun waktu penelitian dilaksanakan pada tanggal 1 Mei 2012 sampai dengan 15 Juni 2012.

Materi yang digunakan pada penelitian ini adalah peternak kelinci di kelompok ternak kelinci "SUMBER LESTARI" Desa Sumber Kecamatan Sanankulon Kabupaten Blitar dengan jumlah kelompok 17 orang. Metode penelitian yang digunakan adalah metode deskriptif yaitu penelitian yang berusaha untuk menuturkan pemecahan masalah yang ada sekarang berdasarkan data-data, jadi penelitian itu menyajikan data, menganalisis dan menginterpretasi (Achmadi dan Narbuko, 2003).

Penelitian kasus adalah penelitian yang mendalam mengenai kasus tertentu yang hasilnya merupakan gambaran lengkap mengenai kasus itu penelitian ini antara lain mencakup keseluruhan siklus kehidupan, kadang-kadang hanya meliputi segmen-segmen tertentu pada faktor-faktor kasus. Studi kasus cenderung untuk meneliti jumlah unit yang kecil tetapi mengenai variabel-variabel dan kondisi yang besar jumlahnya (Achmadi dan Narbuko, 2003). 
Pemilihan lokasi penelitian dilakukan dengan teknik purfosive sampling (sengaja) yaitu berdasarkan pada ciri-ciri sifat-sifat tertentu yang ada dalam populasi yang sudah diketahui sebelumnya (Achmadi dan Narbuko, 2003). Lokasi tersebut dipilih karena memiliki ternak kelinci dengan populasi yang cukup banyak. Sampel yang digunakan pada penelitian ini adalah peternak kelinci di kelompok ternak "SUMBER LESTARI" Desa Sumber dengan populasi ternak kelinci minimal 5 ekor induk betina.

Metode pengumpulan data yang digunakan dalam penelitian ini yaitu dengan melakukan wawancara dengan pertanyaan yang sudah disiapkan, survei, dan observasi (pengamatan).

Data-data yang sudah diperoleh dari penelitian ini dilakukan analisis dengan menggunakan analisis deskriptif yaitu dengan menguraikan data-data yang tersedia dan dihitung dengan menggunakan perhitungan secara matematis.

\section{Hasil Pengamatan Dan Pembahasan}

Pengambilan sampel yaitu di kelompok ternak kelinci "SUMBER LESTARI" yang memiliki ternak kelinci minimal 5 ekor. Pengambilan responden dengan jumlah 17 anggota yang digunakan sebagai sumber data primer untuk informasi identitas kelompok ternak serta keadaan usahanya. Hal ini sesuai dengan pendapat Anonymous (2010), data primer disebut juga sebagai data asli atau data baru yang memiliki sifat up to date yang meliputi umur, jenis kelamin, pendidikan dan tingkat sosial. Karakteristik masing-masing rumah tangga responden mempunyai perbedaan yang diteliti dapat dijelaskan sebagai berikut :

a) Tingkat umur

Tingkat umur dari responden seperti pada tabel 1.

Tabel 1.Responden berdasarkan tingkat umur

\begin{tabular}{|c|c|c|c|}
\hline \multirow{2}{*}{ No } & \multirow{2}{*}{ Umur (tahun) } & \multicolumn{2}{|c|}{ Total Responden } \\
\cline { 3 - 4 } & & Jumlah & $\%$ \\
\hline 1 & $22-39$ & 13 & 77 \\
2 & $40-46$ & 4 & 23 \\
\hline & Jumlah & $\mathbf{1 7}$ & $\mathbf{1 0 0}$ \\
\hline
\end{tabular}

Sumber : Kantor Desa Sumber Mei 2011

Tabel 1. menunjukkan bahwa rata-rata responden mempunyai kelompok umur berkisar antara 22-39 tahun yaitu sebesar 13 responden atau sebesar 77\%. Kondisi umur peternak dapat dijadikan sebagai penentuan untuk dapat mengembangkan usaha ternak kelinci, kondidi umur di kelompok ternak kelinci "SUMBER LESTARI" umunya masih tergolong umur produkstif karena berkisar diantara 20 tahun ke atas dan 50 tahun kebawah.

b) Tingkat pendidikan

Tingkat pendidikan dapat dijadikan sebagai tolak ukur awal untuk mengetahui tingkat kemampuan kelompok ternak kelinci dalam menerima suatu informasi, serta kemampuan dalam menerima dan mengelola usaha ternaknya. Sebagian besar responden telah menjalani pendidikan formal. Adanya pendidikan formal ini diharapkan kelompok ternak labih terbuka terhadap inovasi baru seperti penerapan teknologi usaha dan manajemen usaha yang dapat meningkatkan keuntungan yang optimal. kondisi pendidikan responden di kelompok ternak kelinci "SUMBER LESTARI" tergolong atas sebagian besar berpendidikan SMA yaitu 8 orang sebesar $47 \%$ dari total responden. Tingkat pendidikan responden dapat dilihat pada tabel 2.

\section{Tabel 2. Tingkat pendidikan responden}




\begin{tabular}{|c|c|c|c|}
\hline \multirow{2}{*}{ No } & \multirow{2}{*}{ Tingkat Pendidikan } & \multicolumn{2}{|c|}{ Total Responden } \\
\cline { 2 - 4 } & & Jumlah & $\mathbf{\%}$ \\
\hline 1 & SMP & 7 & 41 \\
2 & SMA & 8 & 47 \\
3 & Sarjana & 2 & 12 \\
\hline & Jumlah & $\mathbf{1 7}$ & $\mathbf{1 0 0}$ \\
\hline
\end{tabular}

Sumber : Data primer diolah (2012)

c) Jenis pekerjaan

Jenis pekerjaan adalah usaha yang sedang dilakukan oleh subyek pelaku. Hal ini sesuai dengan pendapat Anonimous (2010), usaha sambilan dalam peternakan disini bisa diartikan sebagai "side job" artinya yang mempunyai pekerjaan seperti karyawan, PNS, bisa menambahkan penghasilan rumah tangga dengan usaha sambilan ini. Jenis pekerjaan tersebut dikelompokkan atas beberapa macam pekerjaan tertentu yang pernah atau sedang dilakukan pelaku yang bersangkutan. Jenis pekerjaan dan responden peternak dapat dilihat pada tabel 3 . Tabel 3. Jenis pekerjaan kepala rumah tangga responden

\begin{tabular}{|c|c|c|c|}
\hline \multirow{2}{*}{ No } & \multirow{2}{*}{ Pekerjaan } & \multicolumn{2}{|c|}{ Total Responden } \\
\cline { 2 - 4 } & & Jumlah & \% \\
\hline 1 & Buruh tani & 7 & 41 \\
2 & Dagang ternak & 3 & 18 \\
3 & Dagang & 5 & 29 \\
4 & Tani ternak & 2 & 12 \\
\hline & Jumlah & $\mathbf{1 7}$ & $\mathbf{1 0 0}$ \\
\hline
\end{tabular}

Sumber : Data primer diolah (2012)

Tabel 6 menunjukkan bahwa mayoritas responden bermata pencaharian sebagai buruh pabrik yang dijadikan pekerjaan utama. Dan menunjukkan sebanyak 7 responden atau $41 \%$ pekerjaan utama sebagai buruh pabrik. Kondisi pekerjaan rumah tangga di kelompok ternak kelinci "SUMBER LESTARI" didomonasi pada usaha yang bersumber sebagai buruh pabrik. Selain bekerja sebagai buruh pabrik responden juga berternak kelinci sebagai salah satu alternatif pekerjaan untuk menambah sumber penghasilan keluarga.

d) Kepemilikan ternak

Kepemilikan ternak adalah jumlah ternak kelinci yang dimiliki untuk diusahakan atau dipelihara oleh anggota kelompok ternak. jumlah kepemilikan ternak kelinci pada rumah tangga responden dapat dijadikan salah satu tolak ukur ekonomi rumah tangga. Berdasarkan data hasil penelitian menunjukkan bahwa responden di kelompok ternak kelinci "SUMBER LESTAR" memiliki ternak sebanyak 253 ekor dengan rata-rata 14,88 ekor (lampiran 1). Perinciannya terdiri dari induk betina hias 90 ekor (24 ekor jenis hias dan 66 ekor jenis potong), Kelinci jantan 25 ekor (kelinci hias 19 ekor dan kelinci potong 6 ekor), dan jumlah anakan kelinci 138 ekor (19 ekor anakan hias dan 102 ekor anakan kelinci potong). Usaha peternakan kelinci di kelompok ternak kelinci "SUMBER LESTARI" dikategorikan usaha sampingan (sambilan), hal ini sesuai dengan pendapat Anonimous (2010), rata-rata tingkat pendapatan yang dieroleh dari jenis usaha sampingan (sambilan) ini presentasenya $30 \%$ dari total pendapatan.

\section{Modal}

Penggunaan modal adalah penunjang dari kegiatan peternakan oleh kelompok ternak "SUMBER LESTARI" dihitung berdasarkan uang pribadi atau uang pinjaman dari bank. Hal ini sesuai dengan pendapat Anonimous (2012), modal dapat digolongkan berdasarkan sumbernya, bentuknya, berdasarkan kepemilikannya serta berdasarkan sifat. Berdasarkan 
sumbernya, modal dibagi menjadi dua : modal sendiri dan modal asing. Modal sendiri adalah modal yang berasal dari dalam perusahaan sendiri. Modal asing adalah modal yang bersumber dari luar perusahaan. Usaha peternakan rakyat yang dikelola oleh kelompok ternak kelinci "SUMBER LESTARI" tergolong usaha sampingan dalam pengelolaan modal yang terdiri atas pembelian bibit, pembuatan kandang, sewa tanah dan peralatan merupakan modal tetap. Hal ini sesuai dengan pendapat Faisol (2012), biaya tetap yaitu biaya yang dikeluarkan oleh perusahaan yang bersifat tetap dalam rangka operasional perusahaan. Sedangkan pakan, obatobatan, tenaga kerja, dan transportasi merupakan biaya secara total berubah seiring dengan perubahan tingkat aktivitas atau volume yang terkait, hal ini sesuai dengan pendapat (Faisol, 2012).

Tabel 4. Modal usaha ternak kelinci di kelompok "SUMBER LESTARI" (Rp/thn)

\begin{tabular}{|c|l|r|r|}
\hline No & \multicolumn{1}{|c|}{ Uraian } & Toal Modal & \multicolumn{1}{|c|}{$\begin{array}{c}\text { Rata-rata } \\
\text { Rp/thn }\end{array}$} \\
\hline 1 & Harga ternak kelinci hias & 5.100 .000 & 318.750 \\
& Harga ternak kelinci potong & 4.300 .000 & 252.941 \\
2 & Pembuatan kandang lengkap & 14.000 .000 & 823.529 \\
3 & Peralatan kandang & 1.800 .000 & 105.882 \\
4 & Sewa lahan & 170.000 & 10.000 \\
\hline & Jumlah & $\mathbf{2 5 . 3 7 0 . 0 0 0}$ & $\mathbf{1 . 5 1 1 . 2 0 2}$ \\
\hline
\end{tabular}

Sumber : Data primer diolah (2012)

Tabel 7 menunjukkan bahwa total modal usaha ternak kelinci adalah sebesar Rp. 25.370.000 atau Rp. 1.511.202 rata-rata Rp/thn yang terdiri sari Rp. 5.100.000 untuk harga kelinci hias, Rp. 4.300.000 untuk kelinci potong. Pembuatan kandang lengkap Rp. 14.000.000, peralatan kandang Rp. 1.800.000, dan sewa lahan Rp. 170.000. hal ini sesuai dengan pendapat Senduk (2010), modal investasi awal adalah jenis modal yang harus dikeluarkan pada awal memulai usaha, dan biasa dipakai untuk jangka panjang. Pembentukan modal yang bertujuan untuk menunjang pembentukan modal kembali dan juga sebagai pemanfaatan untuk memperoleh suatu pendapat.

\section{Biaya Produksi}

Perhitungan biaya produksi dalam proses usaha merupakan hal yang sangat penting untuk mengetahui besarnya laba yang akan diperoleh. Hal ini sesuai dengan pendapat Faisol (2012) biaya (cost) dalam arti luas biaya pengorbanan sumber ekonomi, yang diukur dalam satuan uang, yang telah terjadi atau yang kemungkinan akan terjadi untuk tujuan tertentu. Biaya meliputi biaya tetap dan biaya tidak tetap. Biaya tetap terdiri atas penyusutan ternak, penyusutan kandang, penyusutan peralatan, dan sewa lahan. Biaya titak tetap meliputi biaya paka, obat-obatan, transportasi, dan tenaga kerja. Untuk lebih jelasnya bisa dilihat pada tabel berikut 
Tabel 5. Total biaya usaha ternak kelinci "SUMBER LESTARI"

\begin{tabular}{|l|lr|lr|}
\hline \multicolumn{1}{|c|}{ Keterangan } & \multicolumn{2}{|c|}{ Total } & \multicolumn{2}{c|}{ Rata-rata Rp/thn } \\
\hline Penyusutan ternak kelinci hias & Rp. & 1.700 .000 & Rp. & 106.250 \\
Penyusutan kelinci potong & Rp. & 1.487 .000 & Rp. & 87.471 \\
Penyusutan kandang & Rp. & 1.230 .000 & Rp. & 72.353 \\
Penyusutan peralatan kandang & Rp. & 578.000 & Rp. & 34.000 \\
Sewa lahan & Rp. & 170.000 & Rp. & 10.000 \\
\cline { 2 - 5 } Total biaya tetap (FC) & Rp. & 5.165 .000 & Rp. & 303.824 \\
\cline { 2 - 5 } Rumput lapang & Rp. & 4.196 .000 & Rp. & 246.824 \\
Dedak/bekatul & Rp. & 8.395 .000 & Rp. & 493.824 \\
Obat-obatan & Rp. & 690.000 & Rp. & 40.588 \\
Transportasi & Rp. & 1.270 .000 & Rp. & 74.706 \\
Tenaga kerja keluarga & Rp. & 13.800 .000 & Rp. & 811.765 \\
\cline { 2 - 5 } Total biaya tidak tetap (V/C) & Rp. & 28.351 .000 & Rp. & 1.667 .706 \\
\cline { 2 - 5 } Total biaya (TC) & Rp. & 33.315 .000 & Rp. & 1.971 .529 \\
\hline
\end{tabular}

Sumber : Data primer diolah (2012)

Adapun komponen-komponen biaya usaha ternak kelinci di kelompok "SUMBER LESTARI" terdiri dari biaya tetap atau fixed cost dan biaya tidak tetap atau variable cost yaitu sebagai berikut :

1. Biaya tetap

Perhitungan penyusutan pada usaha ternak kelinci di kelompok "SUMBER LESTARI" menggunakan metode garis lurus (straight line). Pada tabel 8 total besarnya biaya tetap sebesar Rp. 5.165.000, rata-rata Rp. 303.824 per tahun yang terdiri dari biaya penyusutan kelinci hias sebesar rp. 1.700 .000 rata-rata Rp. 106.250 per tahun dan kelinci potong Rp. 1.487 .000 ratarata Rp. 87.471 per tahun. Penyusutan kandang Rp. 1.230.000/thn rata-rata Rp. 72.353 per tahun, penyusutan peralatan Rp. 578.000 per tahun rata-rata Rp. 34.000 per tahun dan sewa lahan Rp. 170.000 per tahun rata-rata Rp. 10.000 per tahun. Perhitungan dari penyusutan suatu modal yang diinvestasikan kedalam modal tetap akan mengalami beban yaitu beban tetap (fixed cost).

Didalam biaya tetap pasti ada modal awal pembelian bibit ternak. kelompok ternak kelinci "SUMBER LESTARI" memilih bibit ternak yang baik yang berasal dari keturunan, penampilan produksi, reproduksi dan kesehatan yang baik. Hal ini sesuai dengan pendapatan Muharlien, dkk (2008) kelinci yang sehat mempunyai sifat yang lincah, aktif, gerakannya energik, mempunyai nafsu makan yang tinggi, mata bulat bercahaya, selaput mata bersih, serta pandangan mata yang jernih dan cerah. Kepalanya sesuai dengan ukuran badannya, berkaki normal, kokoh dan berkuku pendek, badan bulat, dada lebar dan padat. Harga bibit hias Rp. 150.000 dan kelinci potong Rp. 50.000 di kelompok ternak kelinci "SUMBER LESTARI".

2. Biaya tidak tetap

Biaya operasional dari usaha ternak kelinci "SUMBER LESTARI" yang meliputi biaya pakan, obat-obatan, transportasi dan tenaga kerja adalah biaya tidak tetap. Besarnya biaya tidak tetap sebesar Rp. 28.351.000 per tahun rata-rata Rp. 1.667.706 per tahun. Untuk melihat rincian lebih lengkapnya dapat dilihat pada lampiran 4.

Biaya pakan yang meliputi rumput lapang dan dedak/bekatul adalah Rp. 4.196 .000 per tahun rata-rata Rp. 246.824 per tahun untuk rumput lapang, dan Rp. 8.395 .000 rata-rata Rp. 493.824 per tahun untuk bekatul. Hasil analisa menunjukkan penggunaan biaya pakan dari bekatul lebih besar dari rumput lapang, ini dilakukan oleh kelompok ternak kelinci "SUMBER LESTARI" untuk meningkatkan produksi dan laju kecepatan pertumbuhan. Hal ini sesuai dengan pendapat Sarwono (2005), kelinci membutuhkan karbohidrat, lemak, protein, mineral, 
vitamin dan air. Jumlah kebutuhan tergantung pada umur, tujuan produksi serta laju atau kecepatan pertumbuhan. Sedangkan penggunaan pakan yang kurang maksimal berakibat pada jumlah produksi yang dihasilkan kelinci sangat sedikit. Pakan hijauan di kelompok ternak kelinci "SUMBER LESTARI" diberikan $60-80 \%$ sisa konsentrat.

Tenaga kerja yang digunakan di kelompok "SUMBER LESTARI" adalah dengan tenaga kerja keluarga. Tenaga kerja walaupun berasal dari keluarga sendiri, biaya tenaga kerja yang dianalisis disamakan dengan tenaga kerja yang dibayar dari luar anggota keluarga. Hal ini sesuai dengan pendapat Griffin (2006) tenaga kerja merupakan faktor produksi insani yang secara langsung maupun tidak langsung menjalankan kegiatan produksi. Di kelompok ternak "SUMBER LESTARI" tenaga kerja keluarga setiap harinya dihargai Rp. 10.000 per hari. Seumpama sistem pembayaran tenaga kerja diberikan per bulan sekitar Rp. 300.000.

Bentuk dan ukuran kandang yang akan dibangung sebaiknya memperhatikan kemudahan dalam bekerja, mengontrol dan menghemat waktu dan tenaga dan pengelolaannya sehingga kandang yang baik akan menentukan keberhasilan peternakan karena berperan pada stabilitas kesehatan dan produktivitas kelinci. Hal ini sesuai dengan pendapat Sarwono (2005), perkandangan dan perlengkapannya dalam peternakan kelinci sangat tergantung pada kondisi lokasi, situasi, tingkat usaha dan modal. Di kelompok "SUMBER LESTARI" total modal kandang lengkap Rp. 14.000.000, rata-rata responden sebesar Rp. 823.529 per tahun dengan daya tahan kandang utama 20 tahun dan kandang box (kotak) 5 tahun.

Penyakit ternak kelinci mengakibatkan mortalitas kelinci akibat penyakit cukup tinggi yaitu antara $15.40 \%$ terjadi dari masa kelahiran hingga penyapihan. Faktor penyebabnya adalah sanitasi kandang jarang diperhatikan, pakan yang idberikan berkualitas rendah, volume pakan kurang, air minum kotor, terserang penyakit, perubahan cuaca dan ketidaktahuan peternak mengenai penyakit kelinci. Hal ini sesuai dengan pendapat Hartono dan Rahardi (2003), pengendalian penyakit ternak menjadi salah satu bagian dalam pengendalian produksi ternak. ternak dengan kondisi kesehatan yang baik akan menghasilkan produksi yang optimal. Dengan pentingnya kesehatan ternak, di kelompok ternak kelinci "SUMBER LESTARI" menyediakan obat-obatan untuk mengantisipasi terjadinya penyakit ternak kelinci dengan total biaya Rp. 690.000 rata-rata $\mathrm{Rp} 40.588$ per tahun sehingga dengan obat-obatan tersebut bisa meningkatkan produktifitas ternak dengan akhirnya bisa berdampak pada pendapatan yang diperolehnya.

\section{Penerimaan}

Sumber penerimaan dari usaha ternak kelinci adalah daging dan bulu. Kandungan protein karkas kelinci tinggi, kadar kolesterol yang rendah, otot dagingnya lebih halus, serta secara rasa lebih gurih dan lebih disukai konsumen/ pada umur 8-12 minggu, kelinci potong sudah bisa dipanen. Hal ini sesuai dengan pendapat Alfian (2012), penerimaan adalah jumlah uang yang diperoleh dari penjualan sejumlah output atau dengan kata lain merupakan segala pendapatan yang diperoleh oleh perusahaan hasil dari penjualan produksinya. Hasil total penerimaan dapat diperoleh dengan mengalihkan jumlah suatu barang yang dijual dengan harga barang yang bersangkutan. Hasil penerimaan usaha ternak kelinci "SUMBER LESTARI" dapat dilihat pada tabel 6 berikut.

Tabel 6. Penerimaan usaha ternak kelinci "SUMBER LESTARI"

\begin{tabular}{|c|c|c|c|}
\hline No & Uraian & Total & $\begin{array}{r}\text { Rata-rata } \\
\text { Rp/thn } \\
\end{array}$ \\
\hline 1 & Penjualan anakan kelinci hias umur 2 bulan & Rp. 14.400 .000 & Rp. $\quad 900.000$ \\
\hline 2 & Penjualan anakan kelinci potong umur 2 bulan & Rp. 19.800 .000 & Rp. 1.164 .706 \\
\hline \multirow[t]{2}{*}{3} & Penjualan kelinci afkir hias dan potong & Rp. 1.953 .200 & Rp. $\quad 114.894$ \\
\hline & Jumlah & Rp. 36.153.200 & Rp. 2.126 .659 \\
\hline
\end{tabular}




\section{Sumber : Data primer diolah (2015)}

Data pada tabel 9, penerimaan usaha ternak kelinci "SUMBER LESTARI" pada waktu penelitian menunjukkan bahwa penerimaan dari penjualan anakan kelinci potong yang paling banyak yaitu total Rp. 19.800.000 per tahun rata-rata Rp. 1.164.706 per tahun. Sedangkan penjualan anakan kelinci hias diurutan kedua dengan total Rp. 14.400 .000 rata-rata Rp. 900.000 per tahun dan urutan yang ketiga penjualan kelinci afkir hias dan potong sebesar Rp. 1.953.200 per tahun rata-rata Rp. 114.894 per tahun jadi total jumlah penerimaan usaha ternak kelinci “SUMBER LESTARI” adalah Rp. 36.153.200 per tahun dengan rata-rata Rp. 2.126.639 per tahun. Penerimaan secara lengkap dapat dilihat pada lampiran 6.

\section{Break Event Point (BEP)}

Analisis break event point adalah sebagai patokan bagi peternak dalam barusaha, untuk mengetahui pada jumlah produksi berapa atau penerimaan berupa usaha yang dijalankan tidak menderita kerugian dan tidak mendapatkan keuntungan. BEP menjadi target produksi minimal peternak dalam berusaha agar dapat menjalankan usaha dengan optimal, hal ini sesuai dengan pendapat Firdaus (2012). Kegunaan BEP adalah perencanaan laba (profit planning) hubungan biaya, laba dan volume produksi jauh lebih banyak kegunaannya dari pada hanya sekedar untuk menghitung titik impas. Hubungan ini pun berguna untuk menentukan volume usaha yang diperlukan guna menghasilkan tingkat laba tertentu yang merupakan bagian penting dari perencanaan laba.

Nilai break event point (BEP) dikelompok ternak kelinci "SUMBER LESTARI" berdasarkan produksi anakan rata-rata 99 ekor per tahun dan berdasarkan harga anakan Rp. 18.713 per ekor. Artinya berdasarkan produksi anakan usaha ternak keinci di kelompok ternak tersebut mencapai titik impas saat produksi anakan per tahun sebanyak 99 ekor dan berdasarkan harga anakan usaha ternak di kelompok ternak tersebut mencapai titik impas saat harga anakan sebesar Rp. 18.713 per ekor.

\section{Keuntungan}

Keuntungan atau pendapatan suatu usaha diperoleh dari pengurangan total penerimaan dengan total biaya produksi. Hal ini sesuai dengan pendapat Putri (2008), keuntungan atau nilai lebih yang diperoleh oleh pelaku ekonomi dari hasil penjualan setelah dikurangi modal dan biaya produksi lainnya. Keuntungan pada kelompok ternak kelinci "SUMBER LESTARI" dpat dilihat pada tabel 11.

Tabel 7. Keuntungan/laba usaha ternak kelinci "SUMBER LESTARI"

\begin{tabular}{|l|ll|lr|}
\hline \multicolumn{1}{|c|}{ Keterangan } & \multicolumn{2}{c|}{ Total } & \multicolumn{2}{c|}{ Rata-rata Rp/thn } \\
\hline Penerimaan & Rp. & 36.153 .200 & Rp. & 2.126 .659 \\
Pengeluaran & Rp. & 33.516 .000 & Rp. & 1.971 .529 \\
Keuntungan & Rp. & 2.637 .200 & Rp. & 155.129 \\
\hline
\end{tabular}

Sumber : Data primer diolah (2015)

Dari tabel diatas menunjukkan bahwa keuntungan dari usaha ternak kelinci "SUMBER LESTARI" total sebesar Rp. 2.637.200 per tahun rata-rata Rp. 155.129 per tahun. Hal ini bahwa keuntungan yang diperoleh dari usaha ternak kelinci "SUMBER LESTARI" tergantung jumlah ternak kelinci per ekor.

\section{Kelayakan Usaha Ternak Kelinci "SUMBER LESTARI"}

Kelayakan usaha adalah suatu kegiatan yang mempelajari secara mendalam tentang suatu kegiatan usaha atau bisnis yang akan dijalankan dalam rangka menentukan layak atau tidak suatu usaha tersebut dijalankan. Hal ini sesuai pendapat Ucok (2011) benefit cost ratio $(\mathrm{B} / \mathrm{C})$ merupakan alat analisa untuk mengukur tingkat keuntungan di dalam proses peoduksi 
usaha tani. Sedangkan return cost ratio (R/C) merupakan alat analisa untuk mengukur biaya dari suatu produksi.

Usaha kelompok ternak kelinci "SUMBER LESTARI" termasuk usaha yang layak diusahakan. Hal ini dilihat dari rata-rata nilai R/C di kelompok ternak tersebut 1,074 dan nilai $\mathrm{B} / \mathrm{C}$ sebesar 0,074. Berdasarkan hasil analisis $\mathrm{R} / \mathrm{C}$ sebesar 1,074 menunjukkan bahwa usaha peternakan kelinci di desa tersebut layak diusahakan dan menguntungkan karena nilai $\mathrm{R} / \mathrm{C}$ sebesar 1,074 > 1. Nilai R/C 1,074 artinya bahwa setiap Rp. 1000 biaya yang dikeluarkan dapat menghasilkan tambahan penerimaan sebesra Rp. 1.074. Sedangkan dari hasil analisis B/C sebesar 0,074 memperlihatkan bahwa usaha peternakan kelinci di desa tersebut layak diusahakan dan menuntungkan karena nilai $\mathrm{B} / \mathrm{C}$ sebesar $0,074>0$. Nilai $\mathrm{B} / \mathrm{C}$ sebesar 0,074 artinya bahwa setiap Rp. 1000 biaya yang dikeluarkan untuk usaha peternakan tersebut menghasilkan keuntungan sebesar Rp. 74. Semakin tinggi nilai R/C dan B/C maka usaha tersebut semakin layak untuk diusahakan.

\section{Kesimpulan Dan Saran Kesimpulan}

Hasil penelitian telah dilakukan, besarnya pengeluaran dan penerimaan usaha ternak kelinci "SUMBER LESTARI" adalah sebesar Rp. 1.971 .529 per tahun untuk pengeluaran sedangkan penerimaan Rp. 2.126.659 per tahun. Usaha ternak kelinci di kelompok ternak "SUMBER LESTARI" layak untuk di usahakan. Hal ini dapat dilihat dari nilai R/C sebesar Rp. 1, dan nilai B/C sebesar Rp. 0,074.

\section{Saran}

Pemerintah terkait sebaiknya lebih memperhatikan kembali usaha ternak kelinci dalam hal pemberian penyuluhan dan pelatihan usaha ternak kelinci sehingga semakin banyak orang yang berternak kelinci. Kelompok ternak kelinci "SUMBER LESTARI" dapat meningkatkan populasi kelinci hiasnya untuk lebih mendapatkan keuntungan penjualan.Kelompok ternak kelinci "SUMBER LESTARI" sebaiknya memahami dan dapat menerapkan analisis ekonomi dengan harapan mengetahui tingkat keuntungan yang diperoleh selama menjalankan usaha tersebut.

\section{Daftar Pustaka}

Achmadi, A dan C. Narbuko. 2003. Metode Penelitian. Bumi Aksara. Jakarta

Alfian, M. 2012. Ongkos dan Penerimaan. http://mizan92.wordpress.com/2012/05/05/ongkosdanpenerimaan. 4 Juni 2015.

Anonymous. 2009. Pengertian Studi Kelayakan Usaha. http://eccolife001crp.blogspot.com/2009/01/studikelayakanusaha.html. 4 Juni 2015.

2010.Metode Penelitian. Psp3.ipb.ac.id/ journal/files/journals/1/articles /8/.../8-30-1PB.pdf. 9 Agustus 2015.

...... 2010. Analisa Kelayakan Usaha Budidaya Ikan.
Http://Www.Crayonpedia.Org/Mw
Bab_X_
Analisa
_Kelayakan_

Usaha_Budidaya_Ikan. 4 Juni 2015.

\section{. 2010. Jenis Usaha Peternakan Berdasarkan Skala Usaha.}


http://daemondrock-peternak.blogspot.com/2010/11/jenisusahapeternakanberdasarkan.html. 4 Juni 2015.

.2012. Modal.http://id.wikipedia.org/wiki/faktor_produksi\#Modal. 4 Juni 2015.

Bungin, B. 2008. Penelitian Kualitatif. Kencana Media Group. Jakarta

Faisol, M. 2012. Perilaku Dan Jenis-jenis Biaya. http://faisol.blogspot.com/2012/03/29/Perilaku-dan-Jenis-Jenis-Biaya. 4 Juni 2015.

Firdaus, M. 2012. Manajemen Agribisnis. Bumi Aksara. Jakarta.

Griffin, R. 2006. Tenaga Kerja http://id.wikipedia.org/wiki/Tenagakerja. 4 Juni 2015.

Gulo, W. 2004. Metodologi Penelitian. Grasindo. Jakarta.

Hartono, R dan F. Rahardi. 2003. Agribisnis Peternakan. Penebar Swadaya. Jakarta.

Manshur, F. 2009. Kelinci (Pemeliharaan Secara Ilmiah, Tepat, dan Terpadu). Nuansa. Bandung.

Muharlien, M. E., Sawitri, dan T. E. Susilorini. 2008. Budi Daya 22 Ternak Potensial. Penebar Swadaya. Jakarta.

Putong, I. 2003. Pengantar Ekonomi Makro dan Mikro (edisi 2). Ghalia Indonesia. Jakarta.

Putri, A. D. 2008. Pengertian Ilmu Ekonomi. http://ajengdewantiputri.blogspot.com /2008/09/ pengertian-ilmu-ekonomi.html. 4 Juni 2015.

Rahayu, M. P. 2012. Usaha Tani. http://blog.ub.ac.id/ monahpuji/2012/ 03/07/usahatani. 24 Juni 2015.

Sarwono, B. 2005. Kelinci Potong dan Hias. Agromedia Pustaka. Bandung.

Senduk, S. 2010. Mengenal Macam-Macam Modal Usaha.

http://galeriukm.web.id/permodalan/mengenal-macam-macam-modal-usaha. 4 Juni 2015.

Ucok. 2011. Analisis Data Ilmu Usaha Tani.

http://sayangpetani.wordpress.com/2011/06/16/analisis-data-ilmu-usahatani. 4 Juni 2015 